\title{
2018 Sosyal Bilgiler Öğretim Programının Öğretmen Görüşlerine Göre Değerlendirilmesi: İzmir Örneği ${ }^{\text {a }}$
}

Nalan Altay ${ }^{\mathrm{b}}$

\section{Özet}

Bilindiği gibi öğretim programları çağın ve toplumun ihtiyaçları göz önüne alınarak hazırlanmalıdır. Araştırmanın amacı ülkemizde 2018 yılından beri uygulanan sosyal bilgiler öğretim programı hakkında öğretmenlerin görüşlerini ortaya koymaktır. Bu çalışmada program kazanımları, programın uygulanmasında karşılaşılan sorunlar ve ideal bir sosyal bilgiler programının sahip olması gereken unsurlar öğretmen görüşlerine göre ortaya konmuştur. Bu amaçla İzmir ilinde Millî Eğitim Bakanlığına bağlı devlet okullarında görev yapan 20 sosyal bilgiler öğretmeniyle görüşme yöntemi ile bilgi toplanmıştır. Bu çalışma nitel araştırma yöntemlerinden biri olan durum çalışması şeklinde desenlemiştir. Elde edilen veriler içerik analizi yöntemi ile analiz edilmiştir. Araştırma sonucuna göre, güncellenen program kazanımları hakkında olumsuz görüş belirten öğretmen sayısı olumlu görüş bildiren öğretmen sayısından fazladır. Mevcut programda tarih ve coğrafya disiplinine ilişkin konuların ağır ve yoğun olduğu ortaya konmuştur. Programın uygulanmasında pek çok eksiklik olduğu anlaşılmıştır. Bunlar, ders saatinin az olması, ders kitaplarından kaynaklanan eksiklikler, okulların fiziki yetersizliği, ailelerin sosyo-ekonomik seviyesinden kaynaklı sorunlardır.
Anahtar Kelimeler

Öğretim Programı

Sosyal Bilgiler

Öğretmen Görüşleri

Nitel Araştırma

Makale Hakkında

Geliş Tarihi: 01.04.2020

Kabul Tarihi: 26.08.2020

Doi: 10.18026/cbayarsos.713052

\section{Evaluation of Social Studies Curriculum According to Teachers' Views. Example of Izmir}

\begin{abstract}
As it is known, a curriculum should be prepared considering the needs of the age and society. The aim of the research is to reveal the opinions of the teachers about the social studies curriculum that has been applied since 2018 in Turkey. Program acquisitions, problems encountered in the implementation of the program and the elements that an ideal social studies program should possess are determined according to the opinions of the teachers. This research was designed as a case study, one of the qualitative research methods. The data obtained were analyzed by content analysis method. According to the results of the research, the number of teachers who stated negative opinions about the updated program outcomes is more than the number of teachers who claimed positive opinions about them. It has been revealed that issues related to the discipline of history and geography in the current curriculum are heavy and intense. It turned out that there are many shortcomings in the implementation of the program. These are deficiencies due to the textbooks, physical inadequacy of the schools, problems arisen due to the socio-economic level of families and fewer hours for the lessons.
\end{abstract}

Keywords

Curriculum

Social Studies

Teacher Views

Qualitative Research

About Article

Received: 01.04.2020

Accepted: 26.08 .2020

Doi: 10.18026/cbayarsos. 713052

a Bu makale Manisa Celal Bayar Üniversitesi Bilimsel Araştırma Projesi olarak desteklenmiştir.

b nalankoglu@gmail.com ORCID: 0000-0003-0807-7494 


\section{Giriş}

Öğretim programı, bir dersle ilgili öğretme-öğrenme sürecinde nelerin, niçin ve nasıl yapılacağını gösteren bir kılavuz ve proje planıdır (Özçelik, 1992). Sosyal yaşama uyum sürecinde temel davranışları öğretmek ve toplumsal değerleri kazandırmak (Ozankaya, 2007) amacını taşıyan sosyal bilgiler dersi, günlük yaşamda karşılaşılabilecek sorunlara çözüm bularak, bireyi yaşama hazırlamak gibi çok yönlü bir işleve sahiptir. İnan'a (2014) göre sosyal bilgiler dersinin erdemli insan olmaya rehberlik etmek; etkili vatandaş yetiştirmek, siyasi katılım süreçlerini öğretmek, tarih, mekan ve sosyal düşünme becerilerini öğretmek gibi amaçları vardır. Temel eğitim çağındaki öğrencilerin toplumla kurdukları bağın niteliği, bireyin sağlam bir kişiliğe sahip olmasında Sosyal Bilgiler dersinin önemli bir rolü bulunmaktadır (Aykaç \& Adıgüzel, 2011). Sosyal bilgiler dersi bireyin sosyal yaşayış ve davranışlarına odaklanarak toplumun yararını gözeten ve bunun için gereken becerileri kazanmış bireyler yetiştirmenin yanı sıra sosyal dünyayı kavrayan birey yetiştirmede de diğer derslere göre daha işlevsel bir derstir (Tay, Durmaz, \& Şanal, 2013).

Sosyal bilgiler öğretim programı dünyada ve ülkemizde değişen koşulların farkında olarak, bilgiye dayalı kararlar alıp, problem çözen etkili vatandaşlar yetiştirmek amacıyla gerek sosyal gerekse beşeri bilimlerden aldığı bilgi ve yöntemler ekseninde disiplinler arası bir yaklaşım kullanmaktadı (Öztürk \& Deveci, 2016).

Alanyazın incelendiğinde 2018 sosyal bilgiler öğretim programları hakkında öğretmen görüşlerini içeren çalışmaların yeterli düzeyde olmadığ1 görülür. Çalışmaların 2005 öğretim programının uygulandığ1 yıllarda yoğunlaştığı ortaya çıkmıştır (Semenderoğu \& Gülersoy, 2005; Aykaç, 2007; Gömleksiz \& Bulut, 2006; Doğanay, 2008; Yapıcı \& Demirdelen, 2007; Yıldız \& KIlıç, 2018; Dinç \& Doğan 2010; Gömleksiz \& Curo, 2011; İncekara, 2011; Bahar, Özkaya, \& Birol, 2011; Akpınar ve Aydemir, 2012; Şimşek, 2017).

Alanyazında farklı yıllarda uygulanan öğretim programlarının birbiriyle karşılaştırmasının yapıldığı çalışmalar da bulunmaktadır. Bunlardan biri 2004 ve 2015 sosyal bilgiler öğretim programlarının karşılaştıııldığıni ve 2017 taslak programının önceki programlara göre çok fazla bir yenilik getirmediği ileri süren çalışmadır (Gürel, 2017). Tay (2017) araştırmasında 2005 programı ile 2017 sosyal bilgiler dersi taslak öğretim programlarını hedefler, kazanımlar, içerik, üniteler, vizyon, program yaklaşımı, öğrenme alanları, değerler, beceriler, kavramlar, ara disiplinler, Atatürkçülük konuları, eğitim durumları, öğrenme öğretme süreçleri, değerlendirme boyutları, belirli gün ve haftalar ve etkinlik örnekleri açısından karşılaştırmıştır.

Ülkemizde 2005 ile 2017 yıllarında hazırlanan sosyal bilgiler öğretim programlarının öğrenme alanı/tema, kazanım, kavram, değer ve beceri boyutları açısından karşılaştırılmasının yapıldığı bir çalışmada (Çoban \& Akşit, 2018) bakanlığın 2017 programı olarak sunduğu çalışmanın 2005 programının güncellemesi olduğu ifade edilmiştir. 2017 taslak planı ile ilgili yapılan başka bir çalışma ise Sivas ilinde görev yapan 110 sosyal bilgiler öğretmen ile yapılan çalışmadır. Bu çalışmada tslak programda ders saatlerinin yetersizliği, programın öğrenci seviyesine uygun olmaması, konu yoğunluğu, programın herhangi bir hazırlık olmaksızın uygulanmasının çeşitli sorunlara neden olduğu vurgulanmıştır (Çelikkaya \& Kürümlüoğlu, 2018).

2017 yılı İlkokul Sosyal Bilgiler Dersi Öğretim Programı́nı öğretmen görüşlerine göre değerlendirmek amacıyla yapılan Taş ve Kıroğlu'na (2017) ait çalışma ise Ordu ilinde görev 
yapan 92 sınıf öğretmeni ile 5'li likert tipi ölçekle toplanan verilere dayanmaktadır. Araştırma sonuçlarına göre program hedeflerinin açık ve anlaşılır olduğu, hedeflerin bireye millî, manevi ve evrensel değerleri kazandıracak şekilde hazırlandığı, programın bireyin bilişsel, duyuşsal ve devinişsel yönden bir bütün olarak gelişimini desteklediği sonucuna ulaşılmıştır.

2018 yılından itibaren uygulanan sosyal bilgiler öğretim programı ile ilgili çalışmalar öğretim programının bir ya da birkaç yönüyle analiz edildiği araştırmalardır. Nitekim bunlardan biri Sözen ve Ada (2018) tarafından 2005 ile 2018 sosyal bilgiler öğretim programının incelendiği çalışmada programların içerikleri karşılaştırılmıştır. Bu çalışmada 2018 öğretim programının daha sade olduğu vurgulanmıştır.

Cumhuriyetten günümüze sosyal bilgiler programlarının sosyal bilgiler öğretim yaklaşımlarına göre incelendiği bir çalışma, literatür taraması ile 2017 yılına kadarki öğretim programları betimsel analiz yöntemi ile analiz edilmiştir (Yalçın \& Akhan, 2019). Bu çalışmada 1932, 1938, 1949, 1962, 1970, 1985 tarihli ortaokul programları sosyal bilgiler öğretim yaklaşımlarından vatandaşlık aktarımına ait özelliklere mutlaka yer verildiği saptanmıştır. Ayrıca 1968, 1990, 1998, 2005 ve 2018 programlarında ise diğer programlara göre daha belirgin olarak sosyal bilgilerin üç yaklaşımına (vatandaşlık aktarımı olarak sosyal bilgiler, sosyal bilimler olarak sosyal bilgiler ve yansıtıcı araştırma olarak sosyal bilgiler) ait özelliklere yer verildiği tespit edilmiştir.

Karadeniz (2018) ise 2018 öğretim programında beşeri ve ekonomik coğrafya konularının durumunu betimlediği çalışmada 131 kazanımın 65'inin beşeri ve ekonomik coğrafya konularına ayrıldığını saptamıştır. Bu alanda en fazla konunun 6. sınıf kazanımlarında yer aldığ1 tespit edilmiştir. 2005-2018 öğretim programlarının karşılaştırmalı analizinin yapıldığ başka bir çalışmada programlar betimsel analiz yöntemiyle incelenmiştir. Çalışmanın en önemli bulgusu tarih ve coğrafya disiplinlerine ağırlık verildiğ $i$; antropoloji, arkeoloji ve din bilimi disiplinlerine dair kazanımlara yeterince yer verilmediğidir. Demir \& Haçat, 2018). Sosyal Bilgiler Dersi Öğretim Programı'nın ne tür bir vatandaşlık eğitimi öngördüğününüm incelendiği başka bir çalışmada eleştirel söylem analizi yönteminden yararlanarak öğretim programı analiz edilmiştir. Ortaya çıkan bulgulara göre, 2018 öğretim programının, yoğun olarak geleneksel vatandaşlık eğitiminin, sınırlı olarak ise modern vatandaşlık eğitiminin özelliklerini yansıttı̆̆ ortaya konmuştur (Şen, 2019).

Alandaki bir diğer çalışma 2018 yılında uygulamaya konulan Sosyal Bilgiler Dersi Öğretim Programında yer alan kazanımların Revize Edilmiş Bloom Taksonomisi'ne göre analiz edildiği Filiz ve Baysal'a ait çalışmadır (2019). Bu çalışmada 4. ve 5. Sınıf kazanımlarının çoğunlukla bilişsel süreç boyutuna göre anlama basamağında, bilgi birikimi boyutuna göre ise her iki sınıf düzeyinin de kavramsal bilgi boyutunda yer aldığı tespit edilmiştir. 6. sınıf ve 7.sınıf kazanımlarının bilişsel süreç boyutunda anlama ve analiz düzeyinde kazanımların çoğunlukta olduğu saptanmıştır. Araştırmda üst düzey basamaklarda yer alan kazanım sayısının arttırılması önerilmektedir. 2005 ve 2018 Sosyal Bilgiler öğretim programlarının coğrafi beceriler ile coğrafi kazanımlar alanlarında karşılaştırmasının yapıldığı Çiftçi ve Akça'ya (2019) ait bir çalışma bulunmaktadır. Bu çalışmaya göre 2018 öğretim programında her sınıf bazında coğrafi kazanım alanlarının genişletildiği, analiz ve sorgulama gibi bireysel düşünceleri geliştirmeye yönelik çalışmalara önem verildiği saptanmıştır.

$\mathrm{Bu}$ araştırmanın amacı ülkemizde 2018 yılından beri uygulanan sosyal bilgiler öğretim programı hakkında öğretmenlerin görüşlerini ortaya koymaktır. Bu amaçla 2019- 2020 Eğitim- 
Öğretim Yılında İzmir ilindeki farklı devlet okullarında görev yapan 20 sosyal bilgiler öğretmeniyle görüşmeler yapılmış, görüşme sürecinde toplanan veriler analiz edilerek elde edilen bulgular ortaya konmuştur.

Bu çalışma geleceğin yurttaşlarını yetiştirmede sosyal bilgiler programının önemine dikkat çekerek, mevcut program hakkında öğretmen görüşlerini ortaya koymak amaciyla yapılmıştır. Bu amaçlar çerçevesinde aşağıdaki sorulara yanıt aranmıştır?

1.Sosyal bilgiler öğretim programı kazanımları hakkında öğretmen görüşleri nasıldır?

2.Sosyal bilgiler öğretim programının uygulanabilirliği hakkında öğretmen görüşleri nasıldır?

3.Sosyal bilgiler öğretmenlerine göre ideal bir sosyal bilgiler öğretim programı nasıl olmalıdır?

\section{Yöntem}

Bu bölümde araştırmanın modeli, katılımcı grup, veri toplama araçları, veri toplama süreci, verilerin analizi ile ilgili yöntemsel konular ele alınmıştır.

\section{Araştırma Modeli}

$\mathrm{Bu}$ çalışma nitel araştırma yöntemlerinden durum çalışması şeklinde desenlemiştir. Çünkü görece az sayıda öğretmenle derinlemesine görüşme yapılarak mevcut öğretim programına ilişkin ayrıntılı bilgi elde edinilmesi amaçlanmaktadır (Creswell, 2007). Taylor ve Bogdan'a göre derinlemesine görüşme araştırmacı ile bilgi veren arasında bilgi verenlerin kendi yaşamları, deneyimleri, durumları kendilerini ifade edişlerini anlamaya yönelik yapılan yüz yüze ve tekrarlanan karşılaşmalardır (Kumar, 2011).

Durum çalışması ise; araştırmacının zaman içerisinde sınırlandırılmış bir veya birkaç durumu çoklu kaynakları içeren gözlem, görüşme, doküman, rapor gibi veri toplama araçları ile derinlemesine incelediği, durumların ve duruma bağlı temaların tanımlandığı nitel bir araştırma yaklaşımıdır (Creswell, 2007).

\section{Katılimcılar}

Araştırmanın çalışma grubunu İzmir'de 2019-2020 Eğitim Öğretim yılı birinci döneminde çeşitli devlet okullarında görev yapan 20 sosyal bilgiler öğretmeni oluşturmaktadır. Katılımcılar araştırmaya gönüllü olarak katılmışlardır.

Araştırma katılımcılarının kimlik bilgilerinin gizliliğinin sağlanması amacıyla verilerin sunumunda katılımcıların isimleri yerine Ö.1, Ö.2, Ö.3........̈.20 şeklinde temsiller kullanılmıştır. Katılımcılara ait bilgiler Tablo 1'de gösterilmiştir. 
Tablo 1: Katılımc bilgileri

\begin{tabular}{lllll}
\hline & & & & Son 5 Yılda Hizmet \\
Katılımc1 & Cinsiyet & Mezun olduğu Bölüm & Hizmet Yılı & Durumu Eğitime Katılma \\
\hline Ö.1 & K & Coğrafya Öğretmenliği & 21 & hayır \\
Ö.2 & K & Tarih Öğretmenliği & 20 & hayır \\
Ö.3 & K & Sosyal Bilgiler Öğretmenliği & 19 & evet \\
Ö.4 & K & Tarih Öğretmenliği & 18 & evet \\
Ö.5 & K & Coğrafya Öğretmenliği & 19 & evet \\
Ö.6 & K & Coğrafya Öğretmenliği & 11 & evet \\
Ö.7 & E & Sosyal Bilgiler Öğretmenliği & 14 & evet \\
Ö.8 & E & Sosyal Bilgiler Öğretmenliği & 18 & hayır \\
Ö.9 & E & Sosyal Bilgiler Öğretmenliği & 19 & evet \\
Ö.10 & E & Tarih Öğretmenliği & 28 & evet \\
Ö.11 & K & Sosyal Bilgiler Öğretmenliği & 18 & evet \\
Ö.12 & E & Tarih Öğretmenliği & 24 & evet \\
Ö.13 & E & Tarih Öğretmenliği & 24 & hayır \\
Ö.14 & E & Sosyal Bilgiler Öğretmenliği & 18 & hayır \\
Ö.15 & K & Sosyal Bilgiler Öğretmenliği & 15 & evet \\
Ö.16 & K & Sosyal Bilgiler Öğretmenliği & 16 & evet \\
Ö.17 & K & Sosyal Bilgiler Öğretmenliği & 15 & hayır \\
Ö.18 & E & Tarih Öğretmenliği & 18 & hayır \\
Ö.19 & E & Sosyal Bilgiler Öğretmenliği & 27 & hayır \\
Ö.20 & K & Coğrafya Öğretmenliği & 25 & evet
\end{tabular}

\section{Veri Toplama Araçları}

Nitel araştırma yöntemi esas alınarak hazırlanan bu çalışmada araştırmacı yarı yapılandırılmış görüşme formu oluşturmuştur. Yarı yapılandırılmış görüşme yapılandırılmış ve yapılandırılmamış görüşme türünün bir karışımı olarak hem belirgin hem de açık uçlu soruları içerir (Merriam, 2009). Görüşme soruları oluşturulurken literatürden yararlanılmıştır. Sorular sosyal bilgiler eğitimi alanında görev yapan bir akademisyenin görüşü alınarak düzenlenmiş ve iki sosyal bilgiler öğretmenine yöneltilerek soruların anlaşılırlığı ve amaca uygun olup olmadığ1 yönünde gerekli düzeltmeler yapılarak oluşturulmuştur. Görüşmeler yüz yüze yapılmış, araştırmacı tarafından katılımcıların izni alınarak not edilmiştir. Görüşme sonrasında görüşmeler yazıya aktarılmış ve katılımcılara tekrar gösterilmiş ve katılımcıların görüşme ifadelerini okumaları istenmiştir. Katılımcılardan değişiklik ya da görüşmeye ekleyip çıkaracakları kısımları belirtmeleri istenmiş; 3 katılımcı görüşme metninden bazı ifadeleri çıkarmak istemiştir. Onların istekleri doğrultusunda belirttikleri kısımlar görüşmeden çıkarılmıştır. Elde edilen görüşme formları içerik analizi yöntemi ile incelenmiştir. Bilindiği gibi içerik analizi yöntemiyle elde edilen veriler önce kavramsallaştırılır, bu kavramlar belli bir mantık çerçevesinde düzenlenmiş ve verileri açıklayan kategoriler oluşturulur (Yıldırım \& Şimşek, 2011).

\section{Verilerin Toplanması ve Analizi}

Çözümleme sürecinde görüşme formları araştırmacı tarafından birkaç kez okunmuş ve kodlar oluşturulmuştur. Birbiriyle benzerlik gösteren kodlar sınıflandırılmış; aynı sınıfta yer alan 
kodlara uygun kategoriler oluşturulmuştur. Araştırmanın geçerliliği ve güvenilirliğini belirlemek için araştırmacı üçgenlemesi yapılmıştır. Araştırmacı üçgenlemesi iki veya daha fazla araştırmacının elde edilen nitel verilerin birbirlerinden bağımsız olarak analiz etmesi ve bulguların karşılaştırılmasıdır (Patton, 2014). Ayrıca nitel çalışmalarda geçerliliği arttırmak ve araştırmacının ön yargılarının araştırmaya etkisini engellemek için gözlemlerin tek bir kişi tarafından değil, daha fazla kişi tarafından yapılması gerekmektedir (Büyüköztürk, Çakman, Akgün, Karadeniz, \& Demirel, 2018). Bu doğrultuda veriler, biri araştırmacı diğeri sosyal bilgiler alanında çalışan başka bir akademisyen olmak üzere ayrı alan uzmanı tarafından kodlanmıştır. Daha sonra yapılan kodlama sonuçları karşılaştırılarak uyuşum yüzdesi \%82.6 olarak hesaplanmıştır. Uyuşum yüzdesinin \%70 veya daha üstü olduğu durumlarda nitel araştırmalar güvenilir olarak kabul edilmektedir (Miles \& Huberman, 1994). Böylece araştırmanın güvenilir olduğu ortaya konmuştur.

\section{Bulgular}

Bu bölümde öğretmenlerle yapılan görüşmelerden elde edilen verilerin analiz sonuçları yer almaktadır. Analiz sonuçları tema, kategori ve kodlara ayrılmış, kodlamada esas alınan görüşlerin frekans değerleri tablolarda yer alan kodların yanında parantez içinde gösterilmiştir.

\section{Sosyal Bilgiler Öğretim Programı Hakkında Öğretmen Görüşleri}

Öğretim programı kazanımları hakkında iki alt tema tespit edilmiştir. Bu alt temalara (kategorı) ait kodlar ve kodlara ilişkin frekans değerleri Şekil 1'de verilmiştir.

Şekil 1. Sosyal Bilgiler öğretmenlerinin Program kazanımları hakkındaki düşünceleri

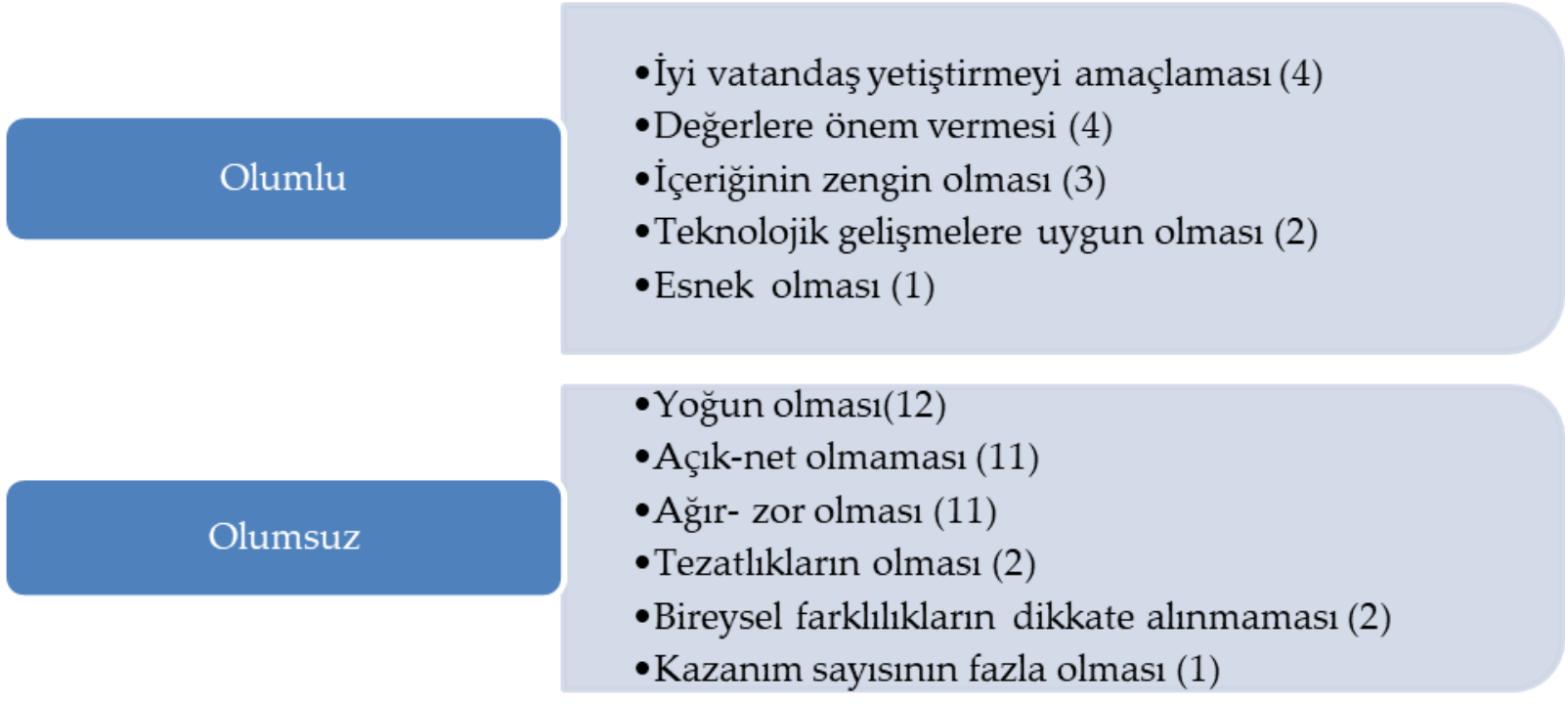

Sosyal Bilgiler öğretmenlerinin büyük bir kısmı (13 öğretmen) 2018 Sosyal Bilgiler öğretim programı kazanımları hakkında olumsuz görüş bildirmişlerdir. Olumsuz görüş belirten Ö.1, Ö.2, Ö.5., Ö.6, Ö.7, Ö.8, Ö.10, Ö.12, Ö.13, Ö.14, Ö.15, Ö.16, Ö.19 kazanımların yoğun bilgi ağırlıklı olduğu, açık ve net ifadeler içermediği, bazı kazanımların ağır ve zor olduğu, tezatlıklar içerdiği, bireysel farklılıkları göz önüne almadan hazırlandığı ve kazanım sayısının fazla olduğunu vurgulamıştır. Öğretmen görüşlerine göre "Kültür ve Miras" öğrenme alanında yer alan tarih disiplini ile ilgili kazanımlar ile "İnsanlar, Yerler ve Çevreler" öğrenme alanında yer alan coğrafya kazanımları ağır ve zordur. İki öğretmen(Ö.4, Ö.20) program kazanımları hakkında olumlu ve olumsuz unsurlar olduğu yönünde görüş belirtmiş; buna 
karşın; yalnızca 5 öğretmen (Ö.3, Ö.9, Ö.11, Ö.17, Ö.18) program kazanımları hakkında olumlu düşünceler ifade etmiştir.Olumlu görüş bildiren öğretmenler programın iyi, sorumlu, aktif yurttaşlar yetiştirmeyi amaçladığını, değerlerimizi ön plana çıkarmaya çalıştığını, zengin bir içeriğe sahip olduğunu ve teknolojik gelişmelere uygun esnetilebilir bir program olduğu yönünde görüş bildirmişlerdir.

"Sosyal Bilgiler öğretim programında yer alan kazanımların temelde iyi, sorumlu ve haklarını bilen; bunları kullanan bireyler olmaya yönelik hazırlandığını görüyorum. Bu nedenle öğretim programını oldukça başarılı bir program olduğunu düşünüyorum" (Ö. 3).

"Program içinde bulunduğumuz koşullara uygun olarak esnek, bireysel özellikleri dikkate alan, bireyin ve toplumun ihtiyaçlarına uygun biçimde iyi ve sorumlu yurttaş yetiştirmeyi gözeten, milli ve manevi değerleri önemseyen, sadece bilgi alan veya aktaran değil sürekli kendini yenileyen, öğrenmeyi öğrenen bireyler yetiştirmeyi hedeflediği için özenle hazırlanmıştır (Ö. 9).

“Program aslında esnek, öğretmene öğretim yöntem ve teknikleri hakkında, yaşamla ilişkilendirilebilmesi noktasında geniş bir alan sunuyor. Ancak mevcut koşullarda bunu pek yaşama geçiremiyorum. Program da ağır ve çok yoğun konular da var. Bitirmek zorunda hissediyorum kendimi. Çünkü çocuklar sınavlara giriyorlar, bilgi vermeden öğrenme eksik kaliyor (Ö.4).

“Çok fazla tezatlıklarla dolu, bir yandan öğrenciyi aktif etmeyi, sınıfta kendini ifade etmesi gerektiğini söylüyor, bir yanda o kadar yoğun ki konuları yetiştireceğiz diye, ya püf noktaları yazdırmak, ya da öğretmen olarak bizler sadece önemli noktaları tekrar tekrar açılamak zorunda kalıyoruz. Kazanımları okuduğumda yeterince açık değil, anlaşılmıyor. Konuyla ilgili hangi bilgi ne düzeyde verilecek net değil; o nedenle konuyu kapsayan bütün bilgileri vermek zorunda kalıyorum" (Ö. 1).

“Çok kötü. Öyle bir program ki yoğun bir bilgi bombardımanı var sanki. Öğrenci seviyesinin çok çok üstünde kazanımlar. Program o kadar ağır ve yoğun ki her şeyi anlatıp geçmek zorunda kalıyorum. Bu kadar yoğun bir programla neyi amaçladığımız çok belli değil" (Ö.2)

"Program çok ağır ve kapsamı çok geniş, ancak en olumlu bulduğum yanı değerlere ve değerler eğitimine önem vermesi, hemen her kazanımda bir değeri işleyebiliyorum. Hak ve sorumluluk konularında davranış geliştirmeye yöneltiyor. Bir yanda da çok zor konular var, Örneğin, Osmanlı tarihi 7. sınıflarda o kadar detaylı ki bir öğrenme alanında 600 yıllık bir imparatorluğa ilişkin neredeyse tüm olayları vermek gerekiyor. Ancak başka bir öğrenme alanında daha hafif ve basit konular olabiliyor" (Ö.5).

“Bir kere çok zor konular var. Örneğin coğrafya konuları, haritalara ilişkin kazanımlar öğrencilerin çok üstünde kalıyor. Aynı şekilde yoğun bir Osmanlı tarihi kazanımları var. Bu kadar yoğun bilgi gerektiren konuları işlerken kesinlikle notlar aldırmam gerekiyor. Püf noktaları kaçırmamaları için kendim tek tek üzerinde duruyorum. Çoğu öğrenci için oldukça zor kazanımlar olabiliyor" (Ö.6).

“Kazanım ifadeleri çok uzun ve kapsayıcı. Çok büyük bir yük, çocuk için de öğretmen için de. Hangi tekniği kullanırsanız kullanın, öğrenciden dönüt alamazsınız (Ö. 7).

“Kapsamı çok geniş, bu kadar çok bilgi yüklemeye gerek var mı? İnsanlar, Yerler ve çevreler ünitesinde mesela o kadar birbirinden bağlantısız konu var ki ve her biri bilgi olmaksızın 
işlenecek konular değil. Tarih konuları da öyle. Mesela; Osmanlı'nın yükselişi, ıslahatlar, yıkılış, sonra kültür ve uygarlık Çok ayrıntı var" (Ö. 12).

“Müfredat çok ağır, yoğun ve iç içe geçmiş. Bir yanda teknoloji, bir yanda tarih, bir yanda coğrafya. Daha önce tarih, coğrafya konuları ayrıydı. Bence daha verimliydi. En fazla ilgi duyulan konular yaşamla ilişkilendirilen konular. Mesela Osmanlının siyasi, ekonomik, kültürel boyutundan bahsediyorsun, bir de Avrupa'yla kiyasliyorsun. 600 yıllık bir imparatorluk. Akademik bilgi verdiğimiz konular çok ağır (Ö. 14).

\section{Sosyal Bilgiler Öğretim Programının Uygulanabilirliğgi Hakkında Öğretmen Görüşleri}

Öğretmenlerin sosyal bilgiler öğretim programının uygulanabilirliği konusundaki görüşlerini içeren tema başlığı altında beş alt tema tespit edilmiştir. Bu alt temalara (kategorı) ait kodlar ve kodlara ilişkin frekans değerleri Şekil 2'de verilmiştir.

Şekil.2. Sosyal Bilgiler öğretmenlerinin Programın uygulanabilirliği hakkındaki görüşleri

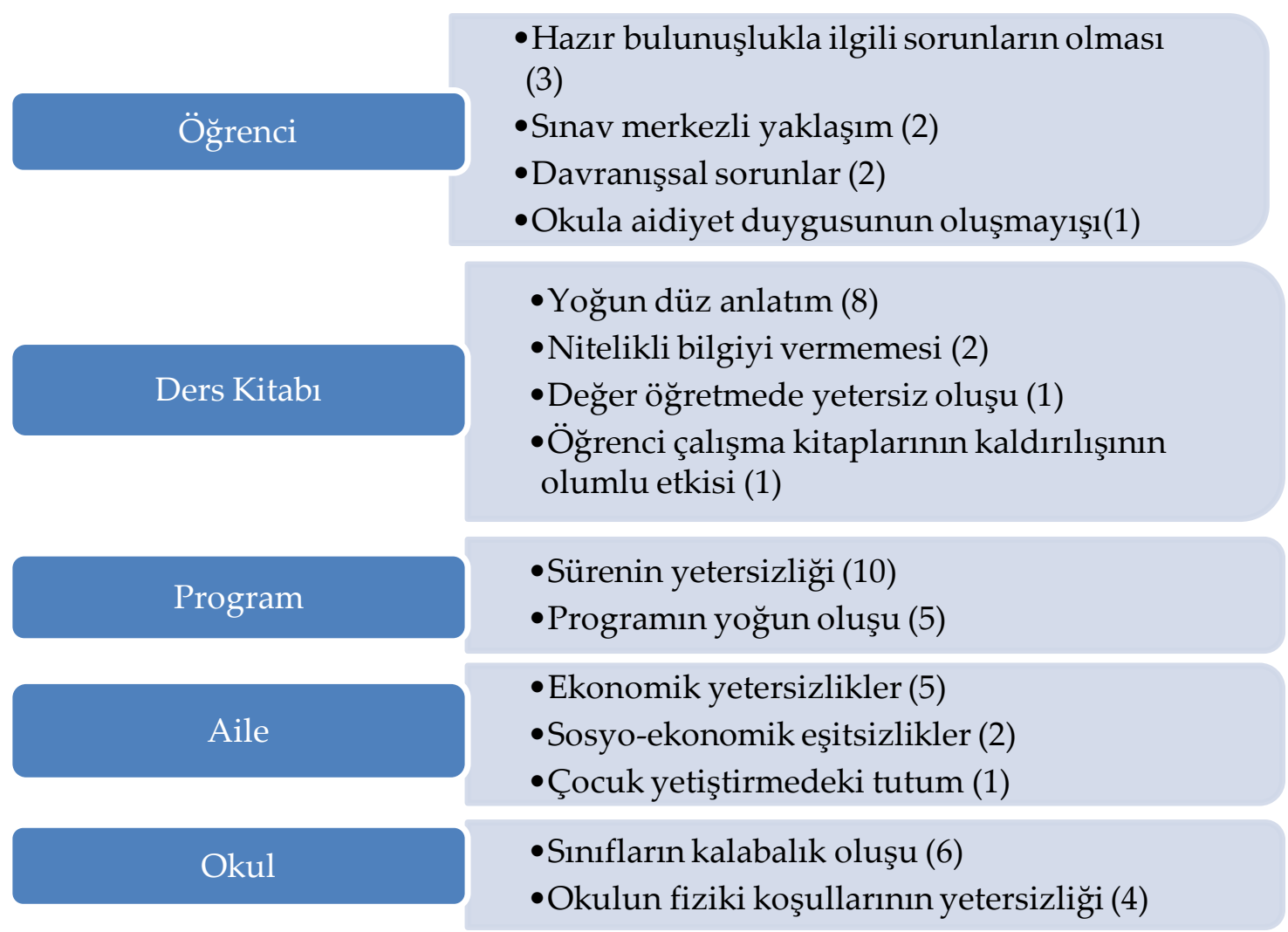

Öğretmenlerin tamamı uygulamada çeşitli sorunlar yaşamaktadır. Ö.4, Ö.5., Ö.,7., Ö.8, Ö.9, Ö.10 bu sorunların öğrencilerin gerek akademik, gerekse davranış açısından yeterli hazırbulunuşluğa sahip olmamaktan kaynaklandığı yönünde görüş bildirmişlerdir. Uygulamada ders kitaplarından kaynaklı sorunların olduğu yönünde görüş bildiren Ö.2, Ö.11, Ö.12, Ö.13, Ö.15, Ö.18 ders kitaplarının öğrencide öğrenme isteği oluşturmada yetersiz olduklarını, özellikle yoğun bilgi ağırlıklı olduklarını, nitelikli bilgiye ulaştırmada yetersiz kaldıkları yönünde görüş bildirmiştir. Ders kitabına yapılan diğer eleştiriler ise yapılandırmacı anlayışa uygun olmadığı, temel değerlerin öğretilmesinde yetersiz oluşu yönündedir. Ders kitaplarının olumlu yönde etkilediği yönünde görüş bildiren Ö. 18 daha 
önce kullanılan öğrenci çalışma kitaplarının kaldırılmasının uygulamayı olumlu yönde etkilediğini ifade etmiştir.

Programın uygulanmasında programın kendisinden kaynaklı sorunlar olduğu yönünde görüş bildiren Ö.3, Ö.4, Ö.6, Ö.14, Ö.15, Ö.18, Ö.19, Ö.20 ders saatinin yetersiz olmasnın ve programın yoğunluğunun programın uygulanabilirliğini etkilediği yönünde görüş bildirmişlerdir. Programın uygulanabilirliğinde aile ile ilişkisi yönünde görüş bildiren Ö.8, Ö.9, Ö.17, Ö.19, Ö.20, ailelerin ekonomik yetersizliklerinin, sosyo-ekonomik farklılıklarının ve çocuk yetiştirmedeki yanlış tutumlarının, programın uygulanmasında olumsuz yönde etkili olduğunu belirtmişlerdir. Okul faktörünün programın uygulanmasındaki etkili olduğunu belirten katılımcılar sınıfların kalabalıklığı ve okulların fiziki yetersizliğinin uygulamada etkili olduğunu ifade etmişlerdir (Ö. 5, Ö.17, Ö.20)

“Programın uygulanabilirliğinden söz etmek mümkün değil. Mesela Üretim Dağıtım Tüketim ünitesini dışarda ya kümes hayvancılığının yapıldığı bir tesise giderek veya bir markette alış veriş yaparak uygulamalı göstermeniz lazım. Bunun için gezi düzenlemek lazım. Bu kadar kalabalık sinıflarda bir de ekonomik nedenler eklenince pek mümkün olamıyor" (Ö. 1).

“Uygulanabilirlik açısından baktığımızda konuların çoğu çocuğun yaşam içerisinde temel beceri ya da uygulama şeklinde hayata aktarılabilecek konulardır. Ancak ders saatlerimiz müfredatın yoğunluğuna göre yeterli olmadığı için çocuklara ekstra bir uygulama yaptırmamız pek mümkün olmuyor" ( Ö. 2).

"Zaten en büyük sıkıntı ders süresinin kısıtlı olmasından ötürü dersi uygulamaya dönük işleyemiyor olmamız. Yani girişimciliği anlatırken bunu çocuk birebir yaşasın, kendisi bir girişim örneği sergilesin bize. Ama biz, bize verilen yoğun müfredatı az zamanda bitirebilme çabası içine girmek zorunda bırakılıyoruz maalesef" (Ö. 3).

“Bu kadar yoğun bir programı haftada üç saatte işlemek çok zor. Bu nedenle bazen kısa geçmek durumunda kalıyorum. Öğrenciler sınavda çıkar mı hangi bilgiyi aklımda tutmalıyım, bu şekilde yaklaşıyor. Bu nedenle önemli noktaları tek tek belirtiyorum" (Ö. 4).

“Uygulamada tabi pek çok sorun var. Öğrenci kendini okula ait hissetmiyor ki, okulda kendine ait bir şey göremiyor. Sınıflar kalabalık, 40 dakikada sadece 1dakika konuşabilir. Kendini ifade edeceği bir yer olarak görmüyor okulu. Okula aidiyet duygusu çok önemli bence; davranış değiştirmek ancak aidiyetin geliştirilmesiyle mümkün olur." (Ö.5).

“Milli ve manevi değerleri oluşturma ve yerleştirme açısından, ders kitapları ve ders süresini yeterli görmüyorum. Programın hedefinin milli değil de evrensel bazı değerleri kazandırmak olduğunu düşünüyorum" (Ö.6).

"Ezbere dayalıyız, araştırmaya dayalı değiliz. Çocuk sınıfa geldiği andan itibaren öğretmen anlatır ben dinlerim, sınavlarda da cevaplarım diye yaklaşıyor. Bu bizim zamanımızdan beri böyle. Araştırma, gezi gözlem yapılması söz konusu olmuyor. Bu kadar kalabalık bir okulda bir gezi varsa sadece sorumluluk bilinci gelişmiş çocukları seçmek zorunda kalıyorum. Çocuklar nerede nasıl davranacaklarını bilmiyor, bunların sorumluluklarını almak çok riskli" (Ö .7).

“Çevre mahallelerde yaşayan çocukların iyi vatandaş olma gibi bir önceliği yok ki, öğrencinin temel problemi düşünme becerisinin zayıf olması, sınıfta kalma yok, okuma yazmayı iyi bilmeyen çocuklar var, bu çocuklara tarih, coğrafya konularını anlatırken zorluklar yaşıyoruz" (Ö. 8). 
"Mevcut öğrenci profili ile çok zor. Vermek istediğim şeyleri tam olarak veremiyorum. Çevre faktörü çok etkili, sorumluluk bilinci ailede başlıyor. Aile yaşantısı, çevresi, internet bizlerin vermek istediklerini kazandırmak istediklerimizi engelleyebiliyor" (Ö .9).

"Uygulamadaki temel sorunlarımızın başında öğrencilerin akademik seviyesinin farklı olması geliyor; bunun temelinde de sosyo-ekonomik farklılıkların bulunması çeşitli zorluklar getiriyor uygulamada. Yine mesela bir sınıf düşünün 40 kişilik, çocuk hiç söz alamıyor. Siz hangi hedefi gerçekleştireceksiniz?" (Ö. 10).

“Ders kitaplarında bir kazanıma karşılık gelen çok konu var. Yani bir kazanımı kazandıracağız ama o kadar yoğun anlatım var ki. Süre yetmiyor bir yandan, bir yandan da kitaplar yetersiz kalıyor. Bizim zamanımız ne güzeldi, ders kitabı varken başka bir kitaba ihtiyaç duymazdın. Karmakarışık şimdiki kitaplar. Maddeleştirilmiş, sistematik hale gelmiş bilgiye ihtiyacımız var. Ders kitabı temel kaynak olmalı, başka kitaba ihtiyaç duymamalı öğrenci" (Ö. 12).

“Çoğu kazanımın kitapta tam karşılığını göremiyorum. Yoğun konu anlatımı var. Uygulama yapabilecek, tartışma ortamı oluşturup farklı etkinlikler düzenleyebilecek zaman sınırlı. Ders saatlerimiz müfredatın yoğunluğuna göre yeterli olmadığ 1 için çocuklara ekstra bir uygulama yaptırmamız da pek mümkün olmuyor" (Ö. 13).

“En büyük sorun sınıf dışında yapılacak gezi, fabrika ziyareti gibi etkinliklerde ekonomik şartlarının yeterli olmaması, okulların fiziki şartlarının yetersiz olması en önemli bunlar. Dışarda yaparak görerek öğrenmesi gereken konuları sınıfta anlatarak işliyoruz (Ö. 14).

“Ders süresinin kısıtlı olmasından ötürü dersi uygulamaya dönük işleyemiyor olmamız. Yani girişimciliği anlatırken bunu çocuk birebir yaşasın, kendisi bir girişim örneği sergilesin bize. Ama biz bize verilen yoğun müfredatı az zamanda bitirebilme çabası içine girmek zorunda birakıliyoruz maalesef" (Ö. 16).

İdeal Bir Sosyal Bilgiler Öğretim Programı Hakkında Öğretmen Görüşleri

Öğretmenlerin ideal sosyal bilgiler öğretim programının nasıl olması gerektiği konusundaki görüşleri hakkında beş alt tema tespit edilmiştir. Bu alt temalar ve onlara ait kodlar Şekil 3'de verilmiştir. Kodlara ilişkin katılımcı sayısı kodların yanında parantez içinde gösterilmiştir. 
Şekil 3. Sosyal Bilgiler öğretmenlerinin ideal sosyal bilgiler öğretim programı hakkındaki görüşleri

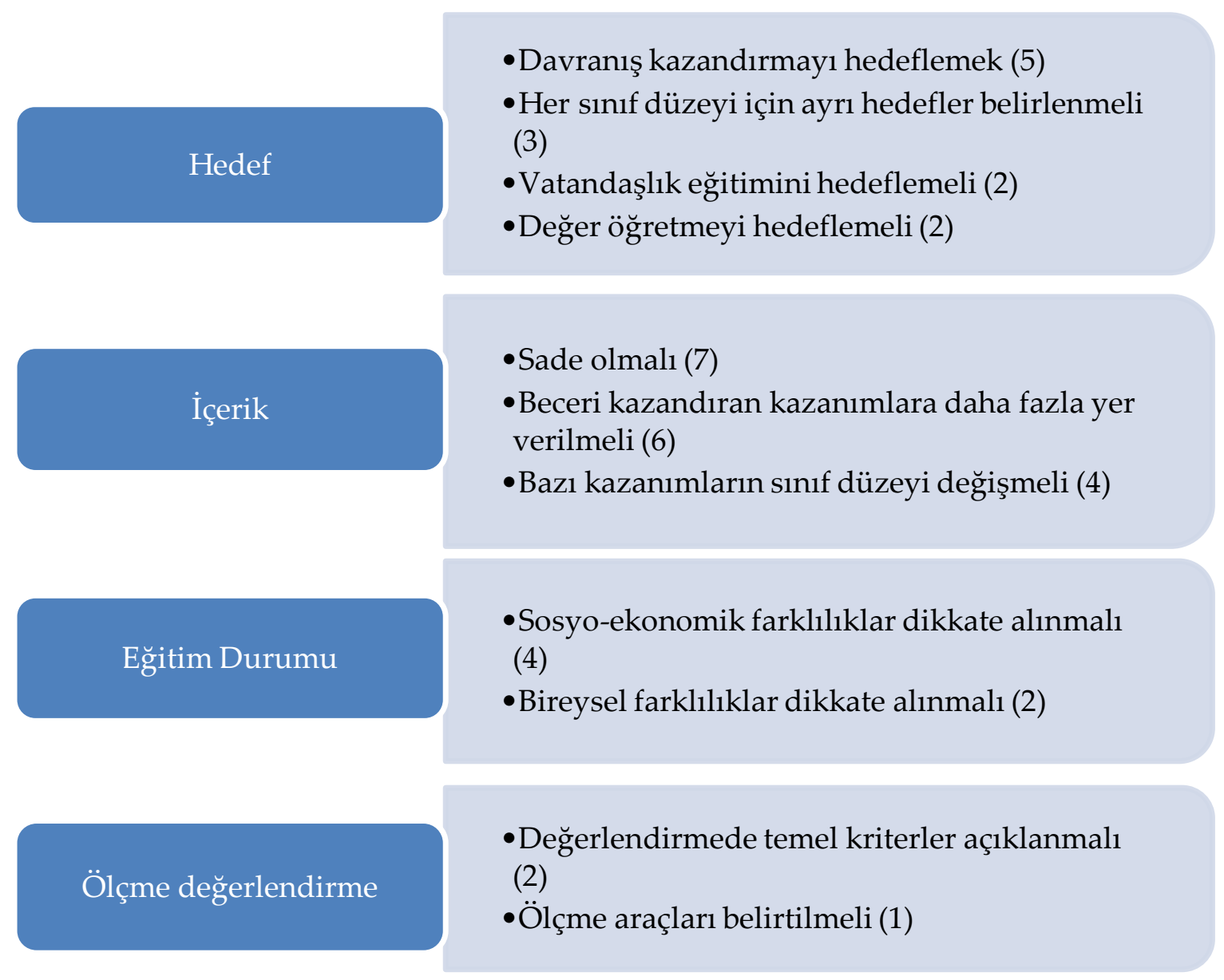

Katılımcılardan Ö. 1, Ö.2, Ö.6, Ö.13, Ö.15, Ö.16, Ö.17 programın hedefleri ile ilgili görüş bildirmişlerdir. Bu katılımclar programın davranış kazandırmayı hedeflemesi gerektiğini, her sınıf düzeyinin hedefleri olması, öncelikle iyi vatandaş olmaya öncelik vermesi ve değerlerin ön planda tutulması gerektiğini ifade etmişlerdir.

Katılımclardan on biri programın içerik boyutu ile ilgili görüş belirtmişlerdir (Ö. 1, Ö.3, Ö.7, Ö.8, Ö.9, Ö.11, Ö. 12, Ö13, Ö.17, Ö.18, Ö.20). Programın şu anki halinden daha sade olması, beceri kazandıran kazanımların sayısının arttırılması ve bazı kazanımların sınıf düzeyinin değişmesi gerektiğini söylemişlerdir.

Eğitim durumu hakkında görüş bildiren katılımcılar Ö.4, Ö.14, Ö.17, Ö.19 programın öğrenciler arasındaki sosyo-ekonomik farklılıklara göre hazırlanması ve öğrencilerin bireysel farklılıklarının da gözetilmesi gerektiğini düşünmektedirler.

Ö.5 ve Ö. 10 programda ölçme değerlendirmeye ilişkin ölçme araçlarının belirtilmesi ve ölçme değerlendirme kriterlerinin de açlk bir biçimde ifade edilmesi gerektiği yönünde görüş belirtmişlerdir.

“Acık ve net olmalı kazanımlar. Kısa ve öz. Bu amaçlar için de öyle, bu kadar çok amaç yerine mesela hangi sınıf düzeyinde amaç dağılımı yapılmalı. Mesela 5. Sınıfta yurttaşlık, bireysel gelişim gibi. 6'da başka amaçlar, 7'de başka amaçları olmalı kademeli olarak amaçlar geliştirilmeli" (Ö.1). 
"Konu odaklı değil de kazanım odaklı olmalı bence, zaten lisede yoğun bir biçimde coğrafya, tarih derslerine ait konular olacak. Biz daha çok davranış kazandırmaya çalışmalıyız diye düşünüyorum. Mesela birçok öğrenme alanında değerlere fazla yer vermiyor. Özellikle İnsanlar, yerler ve Çevreler kazanımında çok fazla değere rastlamadım. Örneğin 6.sınıfta bu kazanımda vatanseverlik değeri yazılmış ama bence bu değer fazla yok" (Ö.2).

“Ders saati artırılmalı, eğer artırılmıyorsa da müfredat çok daha fazla sadeleştirilmeli. Çünkü hala konuları yetiştirebilme çabası içindeyiz. Özellikle her yıl mesela 5 ve 6 'larda hak ve sorumluluklarımızı görüyoruz. Çocuğa hatırlatmak açısından önem arz edebilir ama çocuklar biz bu konuyu hatırliyoruz ve biliyoruz diyorlar. Program daha sade olmalı ama en can alıcı noktalara yer verilmeli. Ancak bu şekilde tam başarıya ulaşabilir düşüncesindeyim" (Ö.3).

“Program bölgesel farklılıklara ve öğrencinin, sınıfın bireysel farklılıklarını gözeterek esnetilebilmeli, her bölgenin hatta aynı şehir içinde mahallelerin bile şartları değişiyor, öğretmene buna uygun esnek bir program sunulmalı" (Ö.4).

"Ölçme ve değerlendirme kriterleri mevcut programda eksik bence. Bu alan tamamen öğretmene bırakılmış durumda, mutlaka ölçme- değerlendirme kısmı açık net belirtilmeli" (Ö.5).

“Kavram öğretimine önem verilmeli bence. Öğrenciler Sosyal Bilgiler kavramlarının çoğunlukla tanımını yapamıyor. Program bilgi değil de değer, beceri ve kazanım odaklı olmalı ve sadeleşmeli" (Ö.6).

“Programda vatandaşlıkla ilişskili konular kazanımlara yedirilmiş. Bu şekilde parça parça olması bence doğru değil. İnsan hakları, demokrasi ve vatandaşlık konuları dersimiz açısından çok önemli ancak bütünlük içinde verilmeli. Program bu konuları çok dağınık ele almış. Dersimizin disiplinler arası olması bu bahsettiğim konuların dağılmasına neden olmamalı, bu konular bir tema altında verilmeli" (Ö.7).

“Bazı temel beceriler ilkokuldan itibaren verilmeli, örneğin ortaokula geldiğinde haritaya bakan bir çocuk bunu nasıl okuyacağını bilmeli, bazı kazanımlar için ortaokul çok geç. Bunlar çok basit düzeyde verilmesi lazım. Mesela iletişim konusu 7. Sınıfta değil ilkokulda olmalı. Biraz daha basitleştirilmeli tarih konuları, zaten var olan program yeterince ağır" (Ö.8).

“Ekonomik faaliyetler, yenilikçilik, girişimcilik ağır geliyor çocuklara. 5. Sınıf için çok erken, vatandaşlık becerileri değil 5. ilkokulda verilmeli, Türk kültürünün sembolleri de öyle. 1 . Sınıftan itibaren kolaydan zora verilmeli. Etkin yurttaşlık da mesela en başta verilmeli" (Ö.9).

“Neyi, ne kadar, nasıl ölçeceğimi programda belirtmemiş, oysa öğretmen bu alanda yeterli mi? Programın ölçme değerlendirme boyutu tekrar gözden geçirilmeli, okuduğumuzda nasıl, hangi araçlarla neleri ölçeceğimizi bilebilmeliyiz" (Ö.10).

"Çevreyi temiz tutma neden önemli, bu verilmeli öncelikli. Program farkındalık kazandırmalı, öncelikli hedefimiz olumlu davranışlar kazandırmak olmalı. Çocuk doğaya gittiğinde ben bunu derste görmüştüm, çöpümü doğaya bırakmamalıyım demeli farkındalık budur bence" (Ö.16).

“Program bilgi değil de değer, beceri ve kazanım odaklı olmalı ve sadeleşmeli. Öğrenciler için zevkli bir hale getirilmeli, Öğrenciler sıkılıyorlar çünkü. Teknolojinin daha fazla kullanımına olanak vermeli" (Ö.17). 


\section{Sonuç ve Öneriler}

Güncellenen öğretim programı hakkında katılımcı öğretmenlerin görüşleri doğrultusunda elde edilen bulgulardan şu sonuçlara ulaşılmıştır:

1. Güncellenen program kazanımları hakkında olumsuz görüş belirten öğretmen sayısının olumlu görüş bildiren öğretmenlerden fazla olduğu görülmüştür. Araştırma sonucunda güncellenen Sosyal Bilgiler dersi öğretim programı kazanımlarının açık olmadığı, zor olduğu, çeşitli tezatlıkları barındırdığı, kazanım sayısının fazla olduğu ortaya çıkmıştır. Elde edilen bulgular Yıldız ve Kılıç (2018)'ın bulgularıyla benzerlik göstermektedir. 2017 taslak programıla ilgili bu çalışmada öğretmenler programın aşama aşama uygulanması gerektiğini, zamanın programdaki etkinliklerin uygulanması için yeterli olmadığını belirtmişlerdir. 2018 yılı programı incelendiğinde bazı kazanımların sınırlılıkları, hangi beceri ve yetkinlikleri içerdiği, diğer derslerle ilişkisi, kazanım verilirken dikkat edilecek hususlar, uyarılar gibi açıklamaların yer almadığı görülmektedir. Öğretmenlerin kazanımların açık olmadığını ifade etmeleri bununla ilişkilendirilebilir. Aynı duruma dikkat çeken Tay (2017) 2018 öğretim programıla büyük benzerlik gösteren 2017 taslak planında kazanım açıklamalarının bulunmadığına dikkat çekmiştir. Ancak bu çalışmada elde edilen bulgular Taş ve Kıroğlu (2017)'nun araştırma bulguları ile örtüşmemiştir. Taş ve Kıroğlu'nun araştırmasında öğretmenler büyük oranda 2017 taslak öğretim planında program içeriğini açık ve anlaşılır bulmuştur. Taş ve Kıroğu!nun 2017 taslak program henüz uygulanmaya başladığ1 yıl çalışmalarını yapmış olmaları bunun nedeni olarak gösterilebilir. Gürel (2017) de 2017 taslak planı ile 2004 planını karşılaştırdığı çalışmada 2017 taslak programında kazanımların yer aldığı temaların disiplinler arası değil, öğrenme alanlarında esas alınan disiplinle sınırlı kalmasını eleştirmiş; temalar ile dersler arası ilişkinin belirtilmemiş olduğuna vurgu yapılmıştır. Çelikkaya ve Çürümlüoğlu (2018)'da 2018 programını değerlendirdiği çalışmalarında 49 öğretmenden 31'i programın yoğun olduğunu ifade etmiştir. Aynı çalışmada 2005 programına göre kazanım sayısı azaltılmakla beraber bazı kazanımların birleştirildiği ve 2005 programında yer almayan yeni bazı kazanımların eklendiği 2018 programının yoğun ve ağır bir program olduğu ortaya çıkmıştır.

2. Araştırma bulgularına göre 2018 öğretim programının uygulanma sürecinde öğretmenler ağırlıklı olarak programın kendisi ve ders kitabı ile ilgili görüş bildirmişlerdir. Katılımcılar ders saatinin az olması nedeniyle sınıf içi- sınıf dışı etkinliklere yeterince zaman ayıramadıklarını ifade etmişlerdir. Çelikkaya ve Kürümlüoğlu (2018) da çalışmalarında sosyal bilgiler öğretmenlerinin, programın uygulanmasında en çok karşılaştıkları sorunlardan birinin ders saatinin azlığı olduğunu ifade etmişlerdir. Haftalık ders saatinin azlığına dikkat çeken bir diğer çalışmada da sosyal bilgiler öğretmenlerinin \%74.95'i ders saatini yeterli bulmamıştır (Taş \& Kıroğlu, 2017).

Bilindiği gibi 2017 yılında ilköğretim ve ortaöğretim ders programları değiştirildikten sonra daha önceki programın uygulanma sürecinde etkili olan çalışma kitapları ve öğretmen kılavuz kitapları kaldırılmıştır. Böylece ders kitabı öğrenci için dersi takip ettiği, temel bilgilere ulaştığı ve kazanımlara uygun farklı öğretim yöntemleri ile hazırlanmış etkinlikler ile derse aktif katılımının sağlandığı ana ders materyali haline gelmiştir. Çalışmada elde edilen bulguya göre ders kitapları konu işleyiş ve anlatım tarzı bakımından yetersizdir. Ders kitaplarının yoğun bir şekilde bilgi verme aracı olduğu, konuların düz anlatımla yazıldığı görüşü yaygındır. 2010 yılında yapılan bir çalışmada da öğretmenlerin önemli bir kısmı ders kitaplarının yeterli düzeyde konuyu işlemediği belirtilmiştir (İncekara \& Karatepe, 2010). Çelikkaya ve 
Kürümlüoğlu (2018)'nun çalışmasında öğretmenlerin önemli bir kısmı ders kitabının hem yoğun hem de sadece bilgi veren bir materyal olduğunu ifade etmişlerdir.

Programın uygulanmasında diğer bir sorun ise sınıfların kalabalık oluşudur. Alanyazında yapılan Kılıç \&Yıldız (2018)'a ait çalışmada sınıfların kalabalık oluşunun sosyal bilgiler dersinin farklı yöntem ve tekniklerle işlenmesi önünde önemli bir engel olduğu vurgulanmıştır. Aynı çalışmada okullardaki fiziksel yetersizliğin de uygulamada önemli bir engel olduğu ortaya çıkmıştır. Bu çalışmada da dört öğretmen okulların fiziki yetersizliğinin dersin uygulanmasında önemli bir sorun olduğunu belirtmişlerdir. Yapıcı \& Demirdelen (2017) ise çalışmalarında programın uygulanmasında en fazla zorluk yaşama durumu olarak sosyal bilgiler öğretmenlerinin \% 61'inin sınıfların kalabalık oluşunu göstermesine dikkat çekmiştir.

Öğretmen görüşlerine göre programın uygulanmasında öğrenci boyutunda etkili olan en önemli faktör öğrenci hazırbulunuşluğu ile ilgili sorunlardır. Hazırbulunuşluk öğrencinin bir öğrenme etkinliğini gerçekleştirebilmesi için gerekli ön koşul davranışları kazanmasıdır (Yılmaz \& Sünbül, 2003). Bu bağlamda öğretmenlere göre öğretim programının uygulanmasında öğrencilerin gerek bilgi, gerek davranış boyutunda hazırbulunuşluklarının zayıf olması önemli bir sorun olarak görülmektedir.

Sınıf; geçmiş yaşantıları, değer yargıları, kültürleri, ilgileri, yetenekleri ve zekâ düzeyleri bakımından farklı özelliklere sahip öğrencilerden meydana gelen bir toplumsal gruptur (Gökyer \& Doğan, 2016). Sınıfta yer alan öğrencilerin gereksinimleri, beklentileri, öncelikleri, hazırbulunuşluk düzeyleri, öğrenme hızları, öğrenme biçimleri, çalışma alışkanlıkları, tutumları, duyguları farklılık gösterir (Sarıtaş, 2006). Bu farklılıklar öğrenci davranışlarının temelini oluşturmaktadır. Gökyer \& Doğan'a göre (2016) istenmeyen öğrenci davranışlarının en sık görülme nedenleri arasında yönetici ve öğretmenlerden, öğrencinin ailesinin, eğitim düzeyinin, gelirinin düşük olması, ailenin ilgisiz olması, yanlış yönlendirmeleri yatmaktadır. Araştırmamızda öğretmen görüşleri bunu doğrulamaktadır. Araştırma bulgularında öğretmenler ailelerden kaynaklanan ekonomik yetersizliklerin programın uygulanmasında etkili olduğu görüşünü ifade etmişlerdir. Uygulamada özellikle gezi, gözlem gibi uygulama çalışmalarının yapılmamasında ekonomik yetersizlikler önemli bir faktör olarak görülmektedir. Aydemir \& Akpınar (2012) çalışmalarında sosyal bilgiler öğretmenlerinin gezigözlem gibi yöntemleri nadiren kullandığını ortaya koymuştur. Ailelerin ekonomik yetersizlikleri öğrenci başarısı üzerinde de etkili bir faktördür. Aslanargun, Bozkurt \& Sarıoğlu (2016)' da öğrencilerin akademik başarıları ile ailelerinin gelir düzeyi arasında pozitif ve anlamlı bir ilişki olduğunu ortaya koymuştur.

3. Bilindiği gibi öğretim programları hedef, içerik, eğitim durumu ve ölçme-değerlendirme unsurlarından meydana gelir. Öğretmenlerin ideal bir sosyal bilgiler programı hakkında görüşleri incelendiğinde hedef boyutunda görüş bildiren öğretmenler öğretim programının temel hedefinin davranış kazandırmak olması gerektiğini ifade etmişlerdir. Bu alanda her sınıf düzeyinin hedeflerinin farklı olması gerektiği yönünde görüş bildiren öğretmenlerin de önemli yer tuttuğunu söylemek gerekir.

İçerik boyutunda görüş bildiren öğretmenler kazanımların sadeleştirilmesi ve bilgi yerine beceri kazandıran kazanımların arttırılması gerektiğini belirtmişlerdir. MEB öğretim programlarını güncellenmesi ile ilgili düzenlediği basın açıklamasında, kazanımlar ile ilgili içeriğin azaltılması için güncel olmayan bilgiler ile yatay ve dikey olarak tekrar eden 
kazanımların eski programlardan çıkarıldığını, kazanımların öğrenci seviyesine uygunluğunun gözden geçirildiğini ve karmaşık kazanımların üst öğretim seviyelerine kaydırıldığını (MEB, 2017) ifade etmiştir. Ancak Çaban\& Akşit (2018) yeni programın kazanımlarının nicel olarak azaltıldığını ancak içerik olarak yani kazanım yoğunluğunun aynı seviyede devam ettiğini ya da arttığını ifade etmiştirlerdir.

Eğitim durumu hakkında görüş belirten öğretmenler, öğrenciler arasında sosyo-ekonomik ve bireysel farklılıklardan kaynaklı sorunların giderilmesinin ideal bir program için önemli bir faktör olduğunu düşünmektedirler. Ölçme değerlendirme boyutunda görüş bildiren öğretmenler ise ölçme araçları ve değerlendirme kriterleri ile ilgili daha açıklayıcı bilgiler olması gerektiğini ifade etmişlerdir. Görel (2017)' in 2017 taslak programının değerlendirildiği makalesinde ölçme değerlendirme ile ilgili çok az bilgi verildiği ifade edilmiştir.

Yukarıda ortaya konan sonuçlara dayanarak şu önerilerde bulunulabilir.

1. 2005 programına göre kazanım sayısı azaltılmış olsa da mevcut kazanımlar uzun ve yoğundur. Bu kazanımların yoğunluğu ve kapsayıcılığı azaltılmalıdır. Bir kazanım içinde birden fazla konu içeren kazanımlar sadeleştirilebilir. Kazanım ifadeleri kısa ve net ifadeler içerebilir.

2. Her bir öğrenme alanında yer alan kazanımlar birbiriyle bağlantılı konuları içermelidir. Kazanımlar arasındaki kopukluk giderilebilir.

3. Etkili öğrenmeyi sağlayıcı üst seviye bilgi ve bilişsel süreç boyutları ile ilgili kazanım sayıları arttırılmalıdır.

3. Öğretim programının ana hedefi belirlenip; 5. 6. ve 7. sınıf düzeyinin her biri için alt amaç veya hedefler belirlenebilir. Haklarımız, sorumluluklarımız, iletişim becerileri gibi temel davranışları içeren konularla ilgili kazanımlar ilkokul hayat bilgisi programından itibaren verilebilir. 4.5.ve 6. sınıflarda davranış ve değer öğretimine ağırlık verilirken, akademik bilgiye odaklanan tarih ve coğrafya konuları 7. ve 8. sinıflarda verilebilir.

4. Dersin uygulanmasında müze, ören yeri, tabiat parkları, bilim merkezleri gibi yerler ile okul çevresinde kazanımlarla ilişki kurulabilecek mekânlara geziler düzenlenmesi teşvik edilebilir. Bu konuda olkullar arası ve öğrenciler arası ekonomik farklılı̆̆ı giderici önlemler alınabilir.

5. Ders kitapları temel bilgilerin bir arada ve sistemli bir şekilde verilip, aynı zamanda farklı öğretim yöntem ve tekniklerinin (hikâye, kanıt kullanma, empati gibi) kullanıldığı ders materyali olarak hazırlanabilir.

\section{Teşekkür ve Bilgilendirme}

Bu çalışma Manisa Celal Bayar Üniversitesi tarafından Bilimsel Araştırma Projesi olarak desteklenmiştir. 


\section{Kaynakça}

Akpınar, B. \& Aydemir, H. (2012). İlköğretim 7. Sınıf Sosyal Bilgiler Öğretim Programının öğretmen görüşlerine göre değerlendirilmesi. Amasya Üniversitesi Eğitim Fakültesi Dergisi 1-1, 41-53.

Aslanargun, E., Bozkurt, S. \& Sarığlu, S. (2016). the impacts of socioeconomic variables on the academic success of the students. Uşak Üniversitesi Sosyal Bilimler Dergisi, 9-3, 214-234.

Aykaç, N. \& Adıgüzel, Ö. (2011). Sosyal Bilgiler dersinde yaratıcı dramanın yöntem olarak kullanılmasının öğrenci başarısına ekkisi. Kastamonu Eğitim Dergisi 19-1, 297-314.

Aykaç, N. (2007). İlköğretim sosyal bilgiler dersi eğitim-öğretim programına yönelik öğretmen görüşleri. Elektronik Sosyal Bilimler Dergisi, 6- 22,, 46-73.

Bahar, H. H., Özkaya, F. \& Birol, N. (2011). 4. sınıf sosyal bġlgğler dersi öğretim programı hakkında öğretmen görüşlerinin değerlendirilmesi (Erzincan örneği). Erzincan Eğitim Fakültesi Dergisi 3-1, 123.

Büyüköztürk, Ş., Çakman, E. K., Akgün, Ö. E., Karadeniz, Ş. \& Demirel, F. (2018). Bilimsel Araştırma Yöntemleri. Ankara: Pegem Yayınları.

Creswell, J. (2007). Qualitative Inquiry \& Research Design: Choosing among five approaches (2. Bask1). USA: Sage Publications.

Çelikkaya, T. \& Kürümlüoğlu, M. (2018). Yenilenen Sosyal Bilgiler Öğretim Programına yönelik öğretmen görüssleri. Uluslar arası Türk Eğitim Bilimleri Dergisi,11, 104-120.

Çiftçi, B. \& Akça, D. (2019). 2005 ve 2018 Sosyal Bilgiler Öğretim Programlarının coğrafi beceri ve coğrafi kazanım alanlarının karşılaştırılması. Eğitimde Yeni Yaklaşımlar Dergisi, 2-1, 33-59.

Çoban, O. \& Akşit, İ. (2018). 2005 ve 2017 Sosyal Bilgiler Öğretim Programlarının öğrenme alanı, kazanım, kavram, değer ve beceri boyutları açısından karşılaştııılması. Tarih Kültür ve Sanat Araştırmaları Dergisi 7-1, 479-505.

Demir, B. \& Haçat, O. S. (2018). Sosyal bilim disiplinlerine göre 2005 ve 2018 Sosyal Bilgiler Dersi Öğretim Programındaki kazanımların değerlendirilmesi. Uluslararası Sosyal Bilgilerde Yeni Yaklaşımlar Dergisi, 2-2, 27-56.

Dinç, E. \& Doğan , Y. (2010). İlköğretim ikinci kademe Sosyal Bilgiler Öğretim Programı ve uygulanması hakkında öğretmen görüşleri. Sosyal Bilgiler Eğitimi Araştırmaları Dergisi, 1(1), 17-49.

Doğanay, A. (2008). Çağdaş sosyal bilgiler anlayışı ışı̆̆ında yeni sosyal bilgiler öğretim programının değerlendirilmesi. Ç.Ü. Sosyal Bilimler Enstitüsü Dergisi, 17-2, 77-96.

Filiz, S. B. \& Baysal, S. B. (2019). Sosyal Bilgiler Dersi Öğretim Programı kazanımlarının revize edilmiş bloom taksonomisine göre analizi. İnönü Üniversitesi Eğitim Fakültesi Dergisi, 20-1, 234-253.

Gökyer, N, \& Doğan, B. (2016). İstenmeyen öğrenci davranışları ve nedenlerine ilişkin yönetici ve öğretmen görüşleri. Fırat Üniversitesi Sosyal Bilimler Dergisi, 26-1, 93-105.

Gömleksiz, M. N. \& Bulut, İ. (2006). Yeni Sosyal Bilgiler Dersi Öğretim Programının uygulamadaki etkililiğinin değerlendirilmesi. Kuram ve Uygulamada Eğitim Yönetimi 303, 393-421.

Gömleksiz, M. N. \& Curo, E. (2011). Sosyal Bilgiler Öğretim Programının toplumsal ihtiyaçları karşılama düzeyine ilişkin öğretmen görüşleri (Diyarbakır ili örneği). Millî Eğitim Dergisi-40, 145165.

Gürel, D. (2017). 2017 taslak sosyal bilgiler öğretim programına yönelik yapısal bir değerlendirme. I. Uluslararası Sınırsız Eğitim ve Araştırma Sempozyumu Tam Metin Bildiri Kitabı (s. 236-248). Sınırsız Eğitim ve Araştırma Derneği.

İnan, S. (2014). Sosyal Bilgiler Eğitimine Giriş, Kavramlar, Yaklaşımlar, Etkinlikler. Ankara: Anı Yayıncilik.

İncekara, S. \& Karatepe, A. (2010). Sosyal bilgiler öğretmenlerinin yeni program temelinde ders kitaplarına yönelik görüşleri. Marmara Coğrafya Dergisi, 46-64. 
Karadeniz, O. (2018). 2018 Sosyal Bilgiler Öğretim ProgramındabBeşerî ve ekonomik coğrafya konularının yeri. 21. Yüzyılda Eğitim ve Toplum, 7-19, 281-295.

Kumar, R. (2011). Araştırma Yöntemleri. Ankara: Edge Akademi.

Merriam, S. (2009). Qualitative research: A Guide to Design and Implementation. San fransisko: CA: Jossey Bass.

Miles, M. \& Huberman, A. (1994). Qualitative Data Analysis. Londra: Sage Yayıncllk.

Ozankaya, Ö. (2007). Toplumbilim. İstanbul: Cem yayınları.

Özçelik, D. (1992). EğitimPprogramları ve Öğretim-genel öğretim yöntemi. Ankara: ÖSYM Yayınları.

Öztürk, C. \& Deveci, H. (2016). Farklı ülkelerin sosyal bilgiler öğretim programları. Ankara: Pegem yayıncilik.

Patton, M. O. (2018). Nitel Araştırma ve Değerlendirme Yöntemleri. Ankara: Pegem Akademi.

Sarıtaş, M. (2006). Öğretmen Adaylarının değerlendirmelerine göre sinıfta istenmeyen öğrenci davranışlarını değiştirmek ve düzeltmek amacıyla yararlanılan stratejiler. Uludağ Üniversitesi Eğitim Fakültesi Dergis, 19-1, 167-187.

Semenderoğu, A \& Gülersoy A.E. (2005). Eski ve Yeni 4-5.sınıf Sosyal Bilgiler Programlarının değerlendirilmesi, Dokuz Eylül Üniversitesi Buca Eğitim Fakültesi Dergisi 18, 141-152.

Sözen, E. \& Ada, S. (2018). 2005 ve 2018 4. sınıf sosyal bilgiler öğretim programının karşılaştırılması. Anadolu Eğitim Liderliği ve Öğretim Dergisi 6 -1, 53-71.

Şen, A. (2019). Vatandaşlık eğitiminde değişiklik ve süreklilikler: 2018 Sosyal Bilgiler Öğretim Programı nasıl bir vatandaşlık eğitimi öngörüyor? Eğitimde nitel araştırmalar dergisi, 7-1, 1-28.

Şimşek, S. (2017). Sınıf Öğretmenlerinin Sosyal Bilgiler Öğretim Programını tanıma yeterlilikleri. Eğitim Kuram ve Uygulama Araştırmaları Dergisi, 3-3, 143-157.

Taş, H. \& Kıroğlu, K. (2017). 2017 İlkokul Sosyal Bilgiler Dersi Öğretim Programı'nın öğretmen görüsslerine göre değerlendirilmesi. İlköğretim Online 17 -2, 697-716.

Tay, B. (2017). 2005 sosyal bilgiler dersi öğretim programı ile 2017 sosyal bilgiler dersi taslak öğretim programının karşılaştırması. International Journal Of Eurasia Social Sciences, 8-27, 461-487.

Tay, B., Durmaz, F. Z. \& Şanal, M. (2013). Sosyal bilgiler dersi kapsamında öğrencilerin değer ve değerler eğitimine ilişkin görüşleri. GEFAD/ GUJGEF 33(1), 67-93.

Yalçın, A., \& Akhan, N. E. (2019). CumhuriyettengGünümüze Sosyal Bilgiler Programlarının Sosyal Bilgiler öğretim yaklaşımlarına göre incelenmesi®. Kuramsal Eğitimbilim Dergisi, 12-3, 842-873.

Yapıc1, M. \& Demirdelen, C. (2007). İlköğretim 4. Sınıf Sosyal Bilgiler öğretim programına ilişkin öğretmen görüşleri. İlköğretim Online, 6-2, 204-212,.

Yıldırım, A. \& Şimşek, H. (2013). Sosyal Bilimlerde Nitel Araştırma Yöntemleri. (9. Baskı). Ankara: Seçkin yayıncılık.

Yıldız, V. A. \& KIlıç, D. (2018). Sosyal Bilgiler dersi öğretim programlarına ilişkin öğretmen görüşleri: bir meta-sentez çalışması. Atatürk Üniversitesi Sosyal Bilimler Enstitüsü Dergisi, 22 (Özel Sayı), 2115-2127.

Yılmaz, H. \& Sünbül, A. M. (2003). Öğretimde planlama ve değerlendirme. Ankara: Mikro Yayınları. 